\title{
Innovation Mix of Development Model Transformation of Chinese Construction Enterprises
}

\author{
Xiao-Hong XIE ${ }^{1, a}$, Yong $\mathrm{LI}^{2, \mathrm{~b}}$ \\ ${ }^{1}$ Xi'an University of Architecture and Technology, Xi'an 710055, Shanxi Province, China \\ ${ }^{2}$ China MCC20 Group Corp. Ltd., Shanghai 201900, China \\ asteven@mccie.com, ${ }^{b}$ liyong@mccie.com
}

Key words: Construction enterprises, Development model, Transformation, Innovation mix.

\begin{abstract}
From the perspectives of partnership theory, value chain theory and knowledge-based economy theory, the present paper came up with three innovative models of development \& transformation for Chinese Construction Enterprises, i.e. alliance, service-oriented construction, and knowledge-based economy; built alliance theoretical model, service-oriented construction theoretical model and knowledge-based economy theoretical model based on detailed theoretical analysis of the said three models, and made systematic study on the way in which construction enterprises improve enterprise performance through the three innovation models; put forward the innovation mix of development models for construction enterprises based on the three innovative development models, and offered a new perspective for construction enterprises seeking transformation and innovation.
\end{abstract}

\section{Introduction}

The global integration facilitates the evolution of large-scale production prevailing in the 20th century into the large-scale collaboration and innovation in the 21 st century. The entire construction industry, especially the highly qualified large-sized construction enterprise groups, have further got involved in market competition along with the rapid development of global market and the expansion of new development space.

According to the international authoritative ENR ranking list, 5 of top 10 construction enterprises have been from China for 3 consecutive years; the rapid development and scale expansion of Chinese Construction Enterprises benefit from the sound momentum of Chinese economic development and the penetrating progress of the Reform and Opening-up. However, in view of the long-lasting low-level dynamic equilibrium with low added value based on labor-intensive low-price volume increment and extensive high-consumption and low-efficiency growth, such "core" issues of Chinese Construction Enterprises as the business model, production organization mode and market operation mode have by no means been remarkably changed, the development model transformation of Chinese Construction Enterprises are faced with realistic hardship and more in-depth reflection.

\section{Enterprise Development Model}

\section{Connotations of Development Model}

Change and Transformation Motives in Development Model of Construction Enterprises. Enterprise development model is normally established for two interrelated purposes, i.e. to maintain steady development of business activities, and to enable adequate flexibility to seek change. Lots of studies showed that the change in development model falls into four different types, i.e. development model creation (I), development model extension (II), development model modification (III), and development mode termination (IV) (Cavalcante et al, 2011) [3]. In practice, the change in development model is normally divided into the said four types; in addition, change of each type may bring about a different extent of innovation. The position and interrelation of changes of the said four types in business activities are as shown in Fig. 1. 


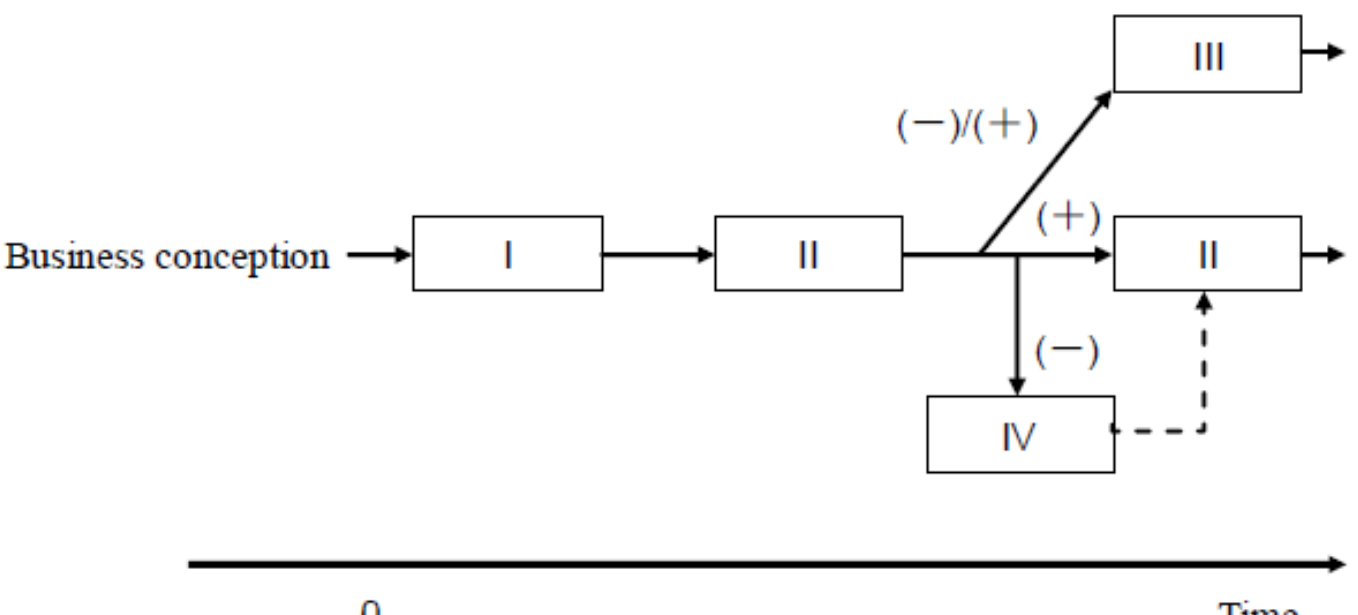

0

Time

Figure 1 Change in enterprise development model

\section{Development Model Transformation of Chinese Construction Enterprises}

\section{Alliance Development Model}

Alliance was first used for project implementation in the United States, and has been widely recognized around the world rapidly since then. Today, alliance model is principally used in North America, Europe, Australia and Hong Kong etc.. A large number of scholars launched studies on alliance model and reported the necessity of application partnership (Construction Industry Institute 1991 [4]; Cowan 1992) [5]. Many scholars hold that alliance should be an effective project implementation method that helps to improve the efficiency and performance of construction industry (Barlow, 2000 [6]; Hauck, Walker, Hampson \& Peters, 2004 [7]).

As a broad concept, alliance manifests the importance of cooperation and coordination between organizations. Alliance could fall into three types depending on the duration thereof, i.e. strategic alliance, project alliance, and organization alliance. When it comes to construction industry, project alliance is more studied. It offers a unique mode of project implementation, which is normally defined as the cooperation between owner and one or more service providers in each implementation stage of project for the purpose of reasonable sharing of risks and benefits (DTF Victoria, 2006) [8]. Under normal circumstances, project alliance for construction industry is a vertical alliance, which links the owner up with other service providers through contractual relationship. As the name implies, project alliance represents a cooperation between organizations established for specific projects and is provided with a definite end node; strategic alliance is normally set up to achieve strategic objectives of the parties concerned, and is not subject to a specific project (Hauck et al. 2004) [7]; organization alliance involves broader organizational extension and process modification.

As for traditional relation, the relation between construction enterprises and partners is based solely on contract. Partnership incorporates cooperative philosophy and represents the relation established between project participants based on trust so as to facilitate the successful implementation of project and benefit all parties concerned; cooperative philosophy exists independent of the contractual relationship. When it comes to alliance, alliance members take the concept of partnership as terms of contract and use it in conjunction with clear benefit and risk allocation to stimulate the management of the entire process of project implementation. In such a case, cooperative philosophy is linked up with contract through the sharing of benefits and risks between project participants. Generally speaking, alliance comprises two essential elements, i.e. formal contract and provisions on benefit/risk sharing, and three flexible elements, i.e. trust, long-term commitment, cooperation \& communication (Yeung et al. 2007) [9].

Among new relationships, alliance gradually evolves into various variants for achieving strategic objective or carrying specific projects into execution, e.g. vertical alliance with own/supplier, 
horizontal alliance with competitors/potential competitors, and multi-disciplinary and multi-industry organizational alliance (for example, restructuring between enterprises based on mixed ownership). According to substantive research $\&$ investigation, the current studies on initial stage of alliance principally focus on three aspects, i.e. alliance motive, alliance establishment principles, and alliance advantage.

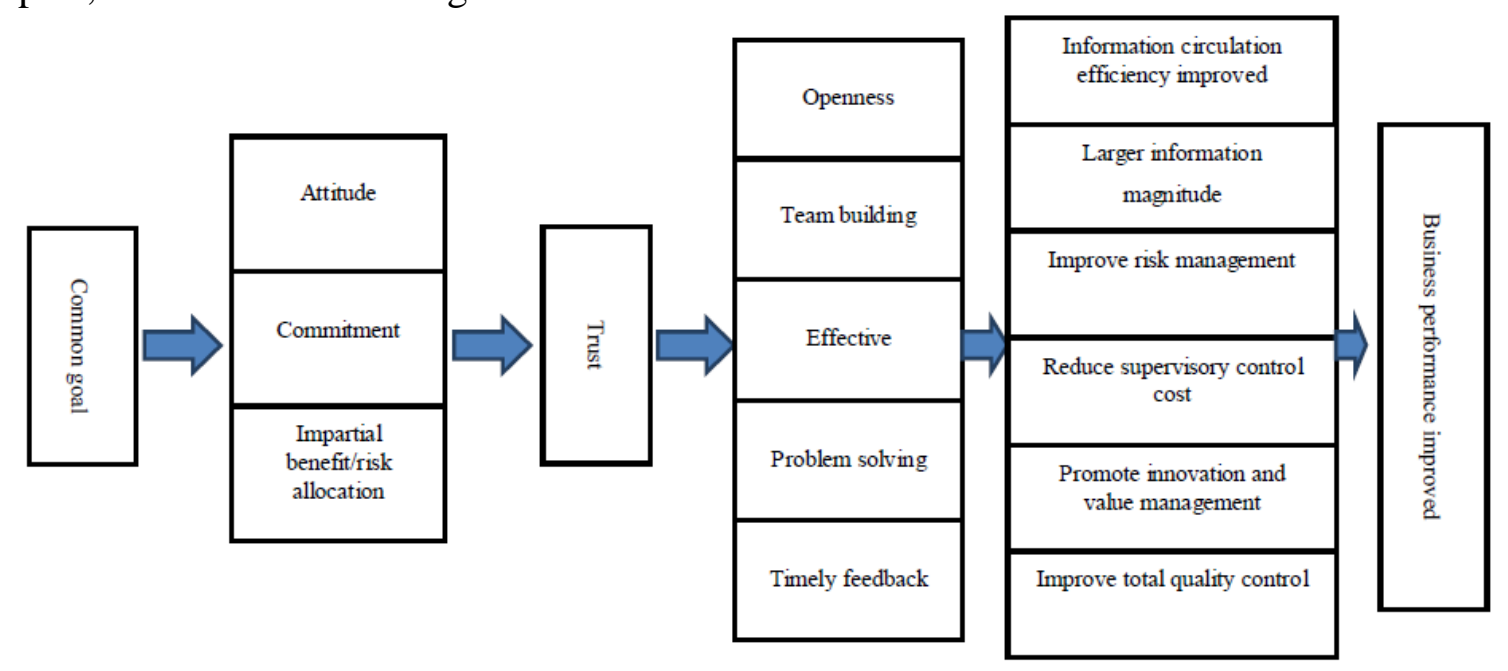

Figure 2 Alliance theoretical model

Key factors for success identified through studies mainly include common goals, attitudes, commitments, equitable benefit/risk allocation, trust, openness, team building, effective communication, problem solving, timely feedback and incentive mechanism. However, the relationship between these factors is not clear (e.g. the factor that helps to raise more value), while no instruction and guidance has been given regarding how these factors help enterprise to improve performance. On this ground, this paper presents an alliance theoretical model (as shown in Fig. 2) and identifies the relation between key factors for success of alliance; this model helps to reveal how alliance promotes enterprise performance improved.

\section{Service-oriented Construction}

As early as the 1970s, Levitt (1972) propose an assumption that every one of us lived in a commercial market of service [10]. Since the 1990s, a great number of scholars have argued that all the industries, including manufacturing and construction industries, are service-oriented industries to some certain extent (Berry and Parasuraman 1991 [11]; Bitner 1997 [12]). Due to market competition and new customer needs, a great many product manufacturing oriented enterprises voluntarily or involuntarily found that they were changing from product sales based traditional model to service based model, as a result of which, they attached greater importance to service and began to provide solutions regarding service and products (Gebauer et al. 2005 [13]; Oliva and Kallenberg, 2003 [14]). Service-oriented construction refers to a construction enterprise development model, by means of which the construction enterprises expand construction industry chain to construction service through the integration of such internal resources as capital, technology and human resources on the basis of traditional business, and provide value-added service or comprehensive solution for service-oriented construction to stakeholders of construction products for the purpose of integration and efficient use of resources and high-efficiency innovation.

Value creation process of an enterprise could be resolved into a series of different and interrelated economic activities, and these value-added activities are realized based on enterprise value chain. With respect of the construction project life cycle, each value creation activity of project represents a value-added process of construction project. In the 1990s, Stan Shih, the founder of ACER INCORPORATED proposed the Smiling Curve (also known as Added Value Curve) [15], which vividly describes the value-added feature of each process in various production and business 
activities: Technology-intensive business activities with higher added value are normally seen upstream and downstream of value added chain, while the labor-intensive business activities with lower added value are normally found at midstream of value-added chain; accordingly, the entire value-added curve is a smiling curve with corners of the mouth upward in appearance (as shown in Fig. 3).

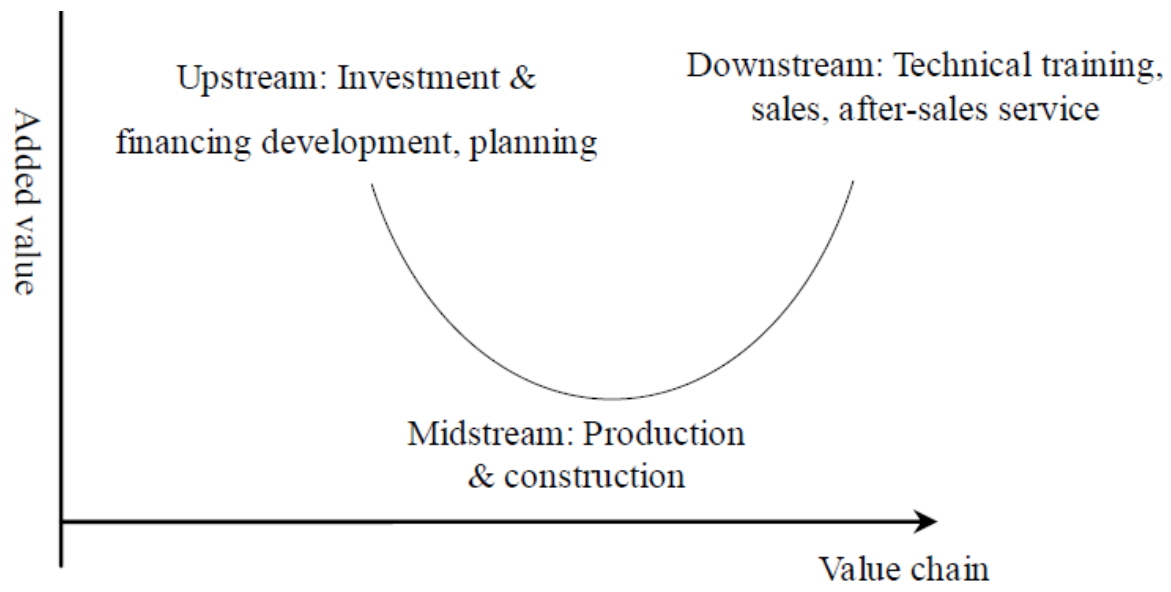

Figure 3 Smiling curve of construction enterprises

Value-added activities along service value chain of construction enterprises normally include investment \& financing, design \& planning, professional consultation, customer support \& training, supply chain coordination and production \& risk management etc. (Gann and Salter, 2000) [16]. By reason that the upper end of smiling curve represents the extent of possibility to obtain high added value, enterprises have to lay stress on extension towards both ends of value chain if they are to obtain greater added value and profit margins. With the growing demand for product and service package, the boundaries between traditional manufacturing, design, construction and service are becoming increasingly blurred; some construction enterprises see themselves as a system integration service provider, and take this as a key competitive advantage.

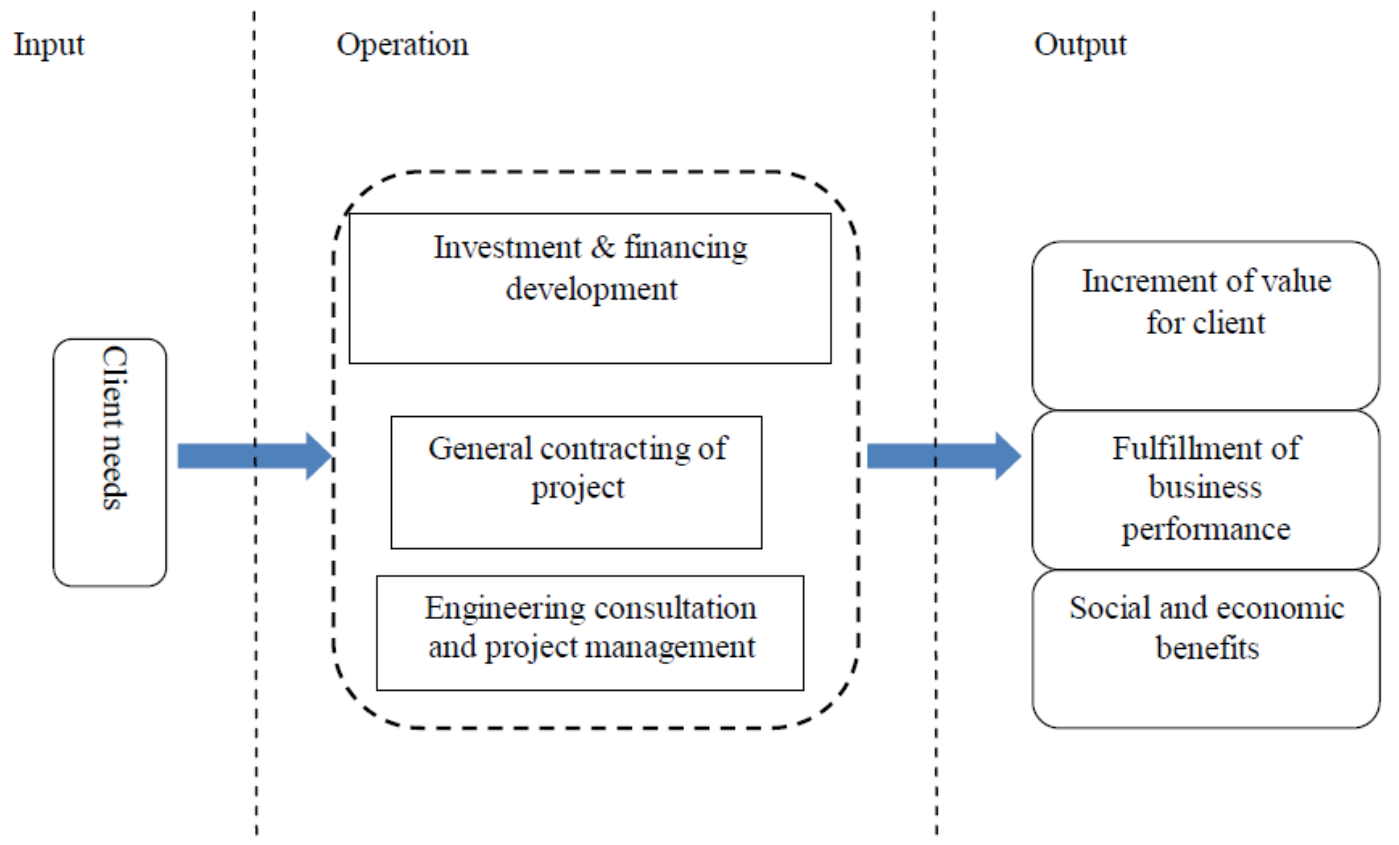

Figure 4 Service-oriented construction theoretical model

When compared with traditional mode of construction, the innovative points of service-oriented construction are principally manifested in the following aspects: From the perspective of relationship with owner, the production \& construction is changed into the satisfaction of owner's 
individual needs; the focus on construction and production is changed into the integration of construction and service; from the perspective of competitive strategy, simplex price competition strategy is changed into differentiated competitive strategy on the basis of production of building products using construction service as a value addition means; as for profit model, seeking meager construction contracting profits is changed into diversified business model based on the extension of profit-making pattern and channel.

The theoretical model of service-oriented construction obtained based on above-noted studies is as shown in Fig. 4.

According to this theoretical model, the implementer of service-oriented construction model should be construction enterprises with certain integrated service capacity and qualification in respect of investment \& financing, general contracting as well as project consulting and management, who provide service to project owner and other stakeholders so as to meet clients' needs, ultimately realize the increase in value of clients and achieve business benefits and social benefits; the core of service-oriented construction model is the process of service-oriented construction, during which the enterprises gain strength based on traditional business and integrate all the resources to expand from original industrial chain to upstream and downstream service so as to provide owner with value-added service or even more comprehensive construction \& development service solutions in respect of financing \& construction, asset operation \& management, real estate and business collaboration, and development and operation of urban public goods etc.

\section{Knowledge-based Economy Model}

In view of the fact that economic growth increasingly relies on knowledge production, distribution and application, the economists called Romer and Lucas proposed the New Economic Growth Theory. Romer took knowledge as an independent endogenous element of economic growth, holding that knowledge helped to improve income on investment, and that knowledge accumulation should be the source of modern economic growth [17]. On the other hand, Lucas projected the progress and accumulation of knowledge and technology into human capital. He argued that the real source of economic growth should be special and profession human capital in the form of labor skill [18]. Knowledge-based economy normally demonstrates the following characteristics: (1) Intellectual resource utilization; (2) Investment in intangible assets; (3) Industrialized use of knowledge; (4) Sustainable economic development; (5) Globalization of the world economy; (6) Virtualization of enterprise development. As we can see, knowledge-based economy is characterized by diffusion and virtualization.

Innovation is the soul of knowledge-based economy. As for construction industry, it is traditionally believed that enterprises give priority to architectural technology innovation and knowledge application (innovation) while being subject to widespread diffusion of technology and knowledge. The integration of construction industry with other industries certainly will bring about new architectural technologies like eco-friendly buildings, green energy-saving buildings, integrated buildings, intelligent buildings as well as residence industrialization and the industrial production of building components \& parts etc.. It is evident that the integration of construction industry with technology industry represents the revolutionary innovation to a certainty. Knowledge-based economy will surely promote the technological innovation and technical application innovation of construction enterprises, radically change the low technology content and backward mode of production in construction enterprises, and push construction enterprises into the development track featuring knowledge-driven productivity advance.

Lots of scholars used market tracks chart to verify that Knowledge-based economy may lead to the failure of veteran large enterprises. Fig. 5 shows a market tracks chart with "profitability of product or service" as X axis and "market size" as Y axis. New products, technologies or services are characterized by small scale and low ratio of gains when they are at the initial stage of commercialization; in this market resulting from knowledge innovation, the improvement of 
business performance resulting from upward value system shift in market is so promising that it can be felt that there is a huge magnet at northeast corner of market tracks chart, which represents the upward mobility of value system [19]. Such an upward thrust force leads to the emergence and development of new products, technologies or services, thus bringing about universal criteria for industry and ultimately resulting in the elimination of leading large enterprises. This is the glamour of connotation extension of knowledge-based economy.

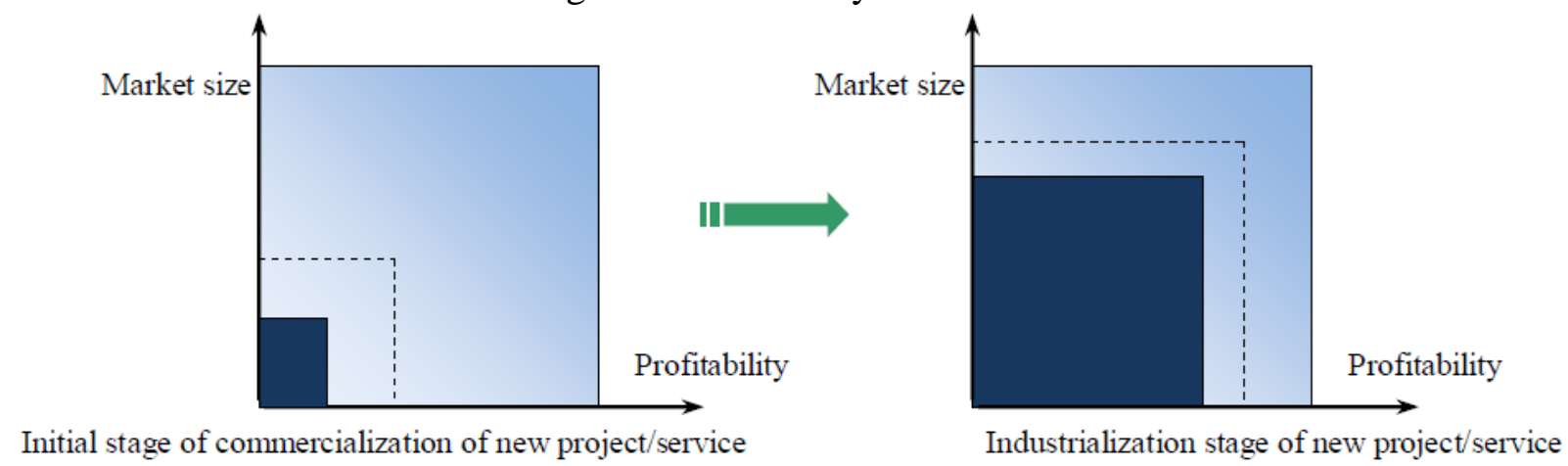

Figure 5 Market tracks chart

Based on the above-noted study, this paper proposed a knowledge-based economy theoretical model (as shown in Fig. 6) to facilitate the performance improvement and innovative development of construction enterprises. The development of knowledge-based economy, as a complex process consisting of "enterprise resource input - internal innovative operation - achievements output", has a bearing upon the establishment of entire organizational framework for construction enterprises, while the knowledge structure and knowledge value chain are considered the innovation source of construction enterprises development. Knowledge value chain involves the internal knowledge chain activities and value chain activities of construction enterprises and the interaction there-between, and its ultimate objective is to realize the increase in value of the entire enterprise; knowledge chain, as the core of construction enterprises knowledge value chain model, is mainly composed of four processes, i.e. knowledge identification \& acquisition, knowledge organization \& storage, knowledge exchange \& sharing, and knowledge application \& innovation [20].

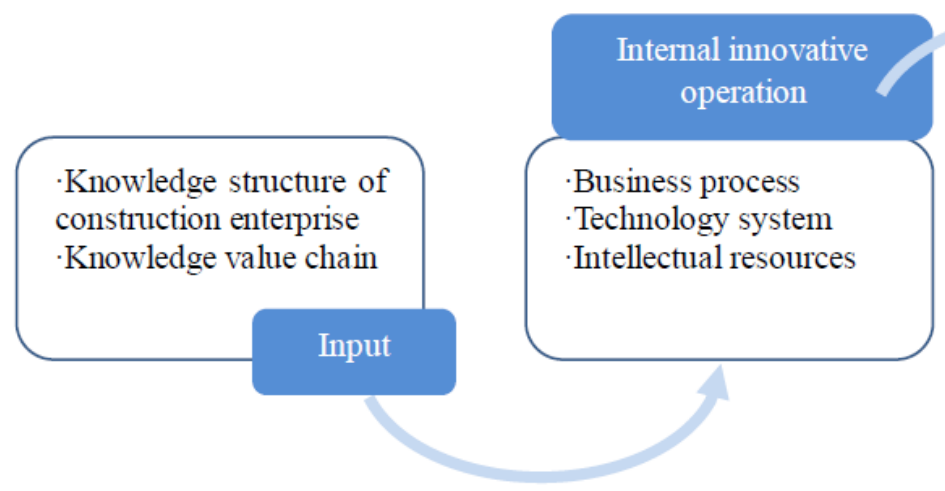

-Performance improvement of construction enterprise

Knowledge assets translated into new market and new competitive edge

Figure 6 knowledge-based economy theoretical model

\section{Three-dimensional Innovation Mix of Development Model Transformation of Chinese Construction Enterprises}

This paper proposed three innovative enterprise development models, i.e. alliance, service-oriented construction and knowledge-based economy models based on partnership theory, value chain theory and knowledge theory in view of the characteristics of construction market and enterprises in China. Table 1 shows the different characteristics of these three innovative development models. 
Table 1 Comparison between the three innovative development models of Chinese Construction Enterprises

\begin{tabular}{|c|c|c|c|}
\hline $\begin{array}{l}\text { Development } \\
\text { model }\end{array}$ & Alliance & $\begin{array}{l}\text { Service-oriented } \\
\text { construction }\end{array}$ & $\begin{array}{l}\text { Knowledge-based } \\
\text { economy model }\end{array}$ \\
\hline $\begin{array}{l}\text { Principal } \\
\text { theoretical basis }\end{array}$ & Partnership theory & Value chain theory & $\begin{array}{l}\text { Knowledge-based economy } \\
\text { theory }\end{array}$ \\
\hline $\begin{array}{l}\text { Innovation } \\
\text { perspective }\end{array}$ & $\begin{array}{l}\text { Cooperative } \\
\text { innovation } \\
\text { Open innovation }\end{array}$ & $\begin{array}{l}\text { Integrated } \\
\text { innovation } \\
\text { Incremental } \\
\text { innovation }\end{array}$ & $\begin{array}{l}\text { Self-dependent innovation } \\
\text { Breakthrough innovation }\end{array}$ \\
\hline Core capacity & $\begin{array}{l}\text { Ability to integrate } \\
\text { industry } \\
\text { resources }\end{array}$ & $\begin{array}{l}\text { Integration of design } \\
\text { and construction } \\
\text { Fund and capital } \\
\text { operation capacity }\end{array}$ & $\begin{array}{l}\text { Knowledge innovation and } \\
\text { achievement application } \\
\text { capacity } \\
\text { Technological innovation } \\
\text { and commercialization } \\
\text { capacity }\end{array}$ \\
\hline Manifestations & $\begin{array}{l}\text { Merger, } \\
\text { combination of } \\
\text { enterprises, } \\
\text { Organization } \\
\text { alliance } \\
\text { (introduction of } \\
\text { mixed ownership), } \\
\text { strategic alliance }\end{array}$ & $\begin{array}{lr}\text { Investment } & \& \\
\text { financing } & \text { and } \\
\text { service integration } \\
\text { (PMC, } \\
\text { MEPCT, BT, BOT), } \\
\text { urban (real estate) } \\
\text { development and } \\
\text { construction } \\
\text { business } \\
\text { collaboration }\end{array}$ & $\begin{array}{l}\text { Industry-university-research } \\
\text { integration } \\
\text { Informatization, } \\
\text { standardization, } \\
\text { industrialization }\end{array}$ \\
\hline $\begin{array}{l}\text { Market } \\
\text { development } \\
\text { characteristics }\end{array}$ & $\begin{array}{l}\text { Powerful alliances } \\
\text { based on integration } \\
\text { of brands, } \\
\text { qualifications, } \\
\text { capital and } \\
\text { customer } \\
\text { relationship } \\
\text { address to to } \\
\text { demand }\end{array}$ & $\begin{array}{l}\text { Extend service chain } \\
\text { - Extend market } \\
\text { demand and perform } \\
\text { customization - } \\
\text { Extend business } \\
\text { space }\end{array}$ & $\begin{array}{l}\text { Create market demand } \\
\text { Seek future customers }\end{array}$ \\
\hline $\begin{array}{l}\text { Implementation } \\
\text { difficulties }\end{array}$ & $\begin{array}{l}\text { Unification } \\
\text { cooperative } \\
\text { philosophy }\end{array}$ & $\begin{array}{l}\text { Creation of } \\
\text { endogenous capacity } \\
\text { Establishment of } \\
\text { support system }\end{array}$ & $\begin{array}{ll}\text { Real conversion from } \\
\text { intellectual resources and } \\
\text { knowledge assets to new } \\
\text { productivity } \\
\text { Continuous input } \\
\text { forward-looking costs }\end{array}$ \\
\hline Ultimate goal & $\begin{array}{l}\text { Large-sized } \\
\text { cross-regional } \\
\text { enterprise } \\
\text { International } \\
\text { business group of } \\
\text { crossover expansion } \\
\text { Incontrovertible } \\
\text { market share }\end{array}$ & $\begin{array}{l}\text { Sophisticated } \\
\text { well-known EPC } \\
\text { general contractor } \\
\text { Urban integrated } \\
\text { operational service } \\
\text { provider } \\
\text { Strong position in } \\
\text { the industry }\end{array}$ & $\begin{array}{l}\text { Shaper of new industry rules } \\
\text { Leader of new industry } \\
\text { order } \\
\text { Maker of new industrial } \\
\text { cluster and new building } \\
\text { ecology }\end{array}$ \\
\hline
\end{tabular}

As can be seen from Table 1, the alliance development model involves various elements input 
and interaction in alliance members and incorporates the interaction between external social and market resources, behaving as an open process of overall integration based on interaction with interior and exterior. New combination outside the organization may occur for the purpose of joint acquisition of new knowledge during innovative development, so this is an open system; however, its implementation difficulties lie in the fact that construction enterprises have to enlarge their own competitive advantage and innovation capability by dint of alliance resources and intelligence; therefore, all alliance members need to exhibit a high degree of consistency in terms of cooperative philosophy.

In the case of service-oriented construction model, most construction enterprises have to take actions for extension towards knowledge- and technology-intensive construction services with higher added value while getting done with traditional business. The building of key abilities and support system is its core factor; for example, the in-depth crossover of design, procurement and construction in EPC project, the effective creation of value engineering, EPC program management, the integration of upstream and downstream resources of industry chain and the organic coordination of capital assets operation with construction business are normally the subjects that have to be profoundly analyzed by construction enterprises during transformation stage, and it may take up to several years or more to finish one of such subjects authentically in some cases.

In the knowledge-based economy model, distinctive innovation-oriented corporate culture provides decision makers with constant driving force for the input of "forward-looking costs", and a research \& development innovation group is normally established in the internal organizational mechanism within enterprise at commercialized development stage of innovative projects or services; on condition that innovative projects or services (e.g. integrated buildings) are sufficient to constitute a new industry, it would be possible to set up new intra-enterprise (subsidiaries, controlled companies etc.) on the technical basis of innovative project and the organizational basis of innovation group to carry out business development activities of innovative services until the industrialization of innovative projects or services. Many enterprises employing knowledge-based economy model seek expeditionary marketing during the development and constantly innovate their governance structure.

Service-oriented construction

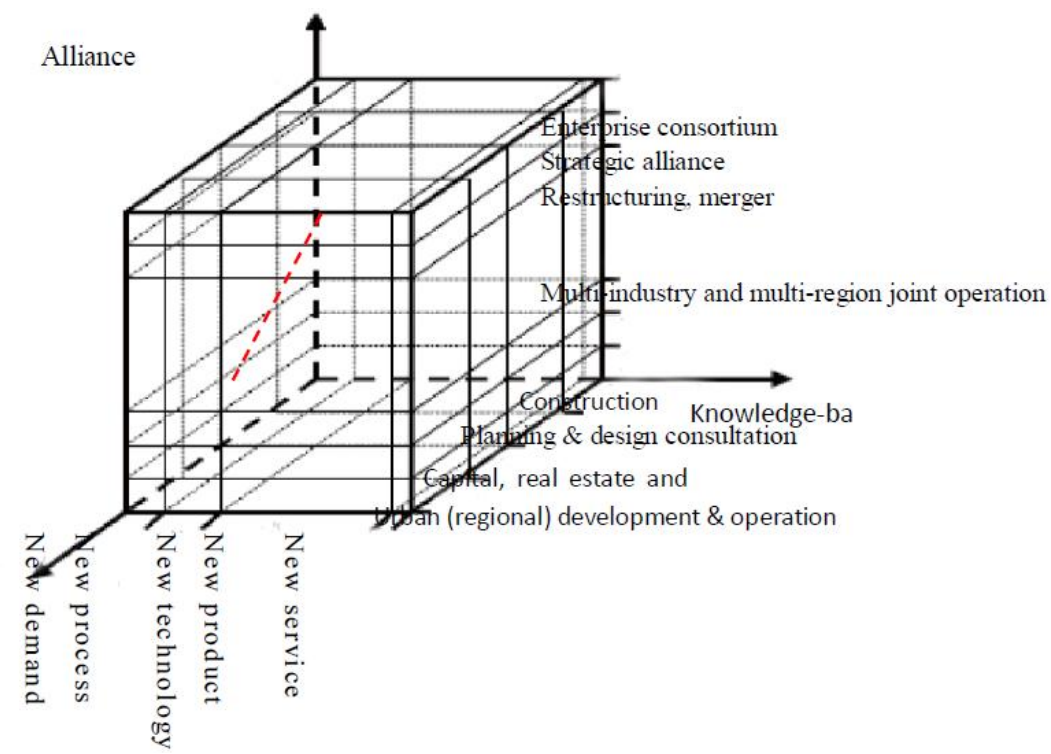

Figure 7 Framework diagram of innovation mix for development models of Chinese Construction Enterprises

The above-noted three innovative development models are distinctive from each other and suit different development stages of enterprise; however, they are not totally independent from each other. This paper is intended to direct enterprise development through the innovation mix analysis of these three models so as to improve business performance.

As the overall conception of development model transformation for construction enterprises (Fig. 
7) and a risk management tool, innovation mix makes it easier to diversify technology, market and customer associated risks and enables enterprises to find better equilibrium of market approaching rate of "revolutionary products or services" and "gradually improved product or service" for the purpose of stable operation. Innovation mix enables leaders of construction enterprises to implement innovation program in an orderly manner and determine the "market entry rhythm" of new products or new services. Innovation mix makes it possible to detect potential opportunities existing in technologies, products, services and markets, thereby helping enterprises to gain more three-dimensional and plump benefits in three dimensions and reduce development risks and costs. The three development models could be carried into execution in a hierarchical manner or exist in parallel in the three-dimensional space of innovation mix.

It thus can be seen that development model transformation or innovation process is also a process of "addition, subtraction, multiplication and division" carried out by enterprises for comprehensive performance improvement, by which means, they could get rid of "the war of red sea" and maximize the values at the right time. Chinese Construction Enterprises, especially large-sized construction enterprise groups are more expected to have the service capacity of full-space expansion, further expedite international market development during the extension of new business portfolio, and thus taking up a strong position in the industry through the combination of incremental innovation and breakthrough innovation and creating system-level competitive advantage so as to turn into the maker of new industry rules and the guider of new industry order and facilitate the formation of next round of new industrial clusters and new building ecologies.

\section{Summary}

In response to the requirement of State-owned Assets Supervision and Administration Commission regarding the cultivation of internationally competitive large modern enterprise groups, China-based construction business has been seeking progressive massive overseas expansion. Some enterprises began to attach importance to endogenous capacity building; for example, such projects as Disney and China Zun launched recently incorporate BIM technology and sustainable construction concept. However, most construction enterprises look powerless in such troubles as inadequate system capacity, poor international competitiveness as well as the barriers that lay stress on intergenerational equity and sustainable construction. Studies on innovative development models of construction enterprises to acquire more in-depth understanding of the way to enhance the cooperation between enterprises and stakeholders and improve business performance through operation management and innovation extension to achieve sustainable development are of important theoretical and practical significance.

This paper made an analysis of correlation theory, partnership theory, value chain theory and knowledge-based economy theory for development model, and proposed three models for innovative development of construction enterprises, i.e. alliance, service-oriented construction and knowledge-based economy models on this basis, having set up construction enterprises innovative development model so as to systematically expatiate the way in which construction enterprises improve business performance through the three innovation models. The proposed three-dimensional innovative mix based development model enables enterprises to find their spatial orientations at any time and clearly discriminate and decide the direction of development model transformation. The studies incorporated in this article offer a new perspective that could be used by Chinese Construction Enterprises seeking transformation \& upgrading for reference.

\section{References}

[1] Hai Yang, Wang Gang, Sun Hui. Interpretation of innovation-Essentials of enterprise development model [M]. China Machine Press, 2004.2:27-40.

[2] Yang Aihua. A study on the selection of enterprise development model [D]. Shandong University, 2006. 
[3] Cavalcante S, Kesting P, Ulhøi J. Business model dynamics and innovation: (Re) establishing the missing linkages[J].Management Decision, 2011, 49(8): 327-1342.

[4] Construction Industry Institute (CII).In search of partnering excellence [M].Construction Industry Development Agency, 1991.

[5] Cowan C. Partnering-A concept for success. Master Builders, Australia, 1992.

[6] Barlow J. Innovation and learning in complex offshore construction projects[J].Research Policy, 2000, 29(7): 973-989.

[7] Hauck A J, Walker D H T, Hampson K D, et al. Project alliancing at National Museum of Australia-collaborative process[J].Journal of Construction Engineering and Management, 2004, 130(1): 143-152.

[8] DTF Victoria. Project Alliancing: Practitioners' Guide [J]. The Department of Treasury and Finance, State of Victoria, Melbourne, 2006.

[9] Yeung J F Y, Chan A P C, Chan D W M. The definition of alliancing in construction as a Wittgenstein family-resemblance concept[J].International Journal of Project Management, 2007, 25(3): 219-231.

[10] Levitt T. Production-line approach to service[J].Harvard business review, 1972, 50(5): 41-52.

[11] Berry L L, Parasuraman A. Marketing Services, Competing Through Quality[M].The Free Press, New York, 1991.

[12] Bitner M J. Services marketing: perspectives on service excellence[J].Journal of Retailing, 1997, 73(1): 3-6.

[13] Gebauer H, Fleisch E, Friedli T. Overcoming the service paradox in manufacturing companies[J].European Management Journal, 2005, 23(1): 14-26.

[14] Oliva R, Kallenberg R. Managing the transition from products to services[J].International Journal of Service Industry Management, 2003, 14(2): 160-172.

[15] Chen Pang, Zheng Yicun. Inspiration of "smiling curve" theory for industrial structure supererogation in China [J]. Market Forum, 2006, 11.

[16] Gann D M, Salter A J. Innovation in project-based, service-enhanced firms: the construction of complex products and systems[J].Research policy, 2000, 29(7): 955-972.

[17]Paul M. Romer.The Origins of Endogenous Growth.The Journal of Economic Perspectives[J].

Vol. 8, No. 1 (Winter, 1994): 3-22

[18] Gong Zhiguo. Western Economics [M]. Electronic Industry Press, 2009

[19] Christensen, Clayton M. The innovator's dilemma: when new technologies cause great firms to fail [M]. Boston, Mass. : Harvard Business School Press, c1997.

[20] Li He. Knowledge management-based business organization innovation research [D]. Jilin University, 2006. 